\title{
LEAVES OF GRASS AND REAL ESTATE
}

\author{
Peter J. L. Riley
}

I.

DAVID Dowling HAS RECENTLY ARGUED that Whitman's construction of the 1855 Leaves of Grass was a conscious process of commodification. In Dowling's view, the poet disguised his sales-pitch with a marketable anti-materialist rhetoric which was in itself a commodity: "Whitman was as much a creature of the literary marketplace as his poet figure

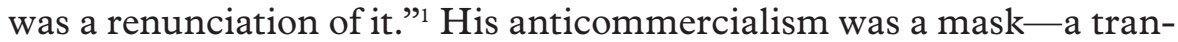
scendent persona designed to sell books; Whitman was forging an early type of book selling that wedded organic ornament with consumerism. Dowling goes on to say that:

Sorting out the economic ethos behind Whitman's construction of his ideal poet illuminates Whitman's overall scheme of self-promotion that was so well attuned to the market revolution. He anticipates modern commercial methods that romanticize products through metanarratives of escape, mystification, and transcendence-available of course through cash exchange - of the very economic world both producer and consumer inhabit. For Whitman, aesthetic decisions were professional decisions, and artistic choices were financial choices. (84)

Whitman as savvy marketing strategist of his own literary career has always cut an intriguing figure. This was after all the man who, for publicity purposes, was so ready to stamp Emerson's words of praise on the spine of his 1856 edition. But Dowling's reading does not quite tally with the sustained intensity of Whitman's vision, nor does it account for his distinctive stylistic innovations. There seems to be little doubt that Whitman had conviction in what he was writing, so to explain the "metanarratives of escape, mystification and transcendence" as antimaterialist marketing strategies is to cast Whitman as too calculating a figure. He was more accident-prone than that-more complicated and sincere.

Recent work by Ed Folsom has shown that many of the distinctive features of the 1855 book actually came about by chance. He suggests for example that the unusual formatting of Leaves was the result of the Rome Brothers only having contractual, legal paper to hand at the time 
of printing. Most of their commissions were legal documents and this was the only paper size they had in stock when Whitman approached them. The poet was consequently forced to rethink the entire layout of his book. ${ }^{2}$ Folsom also contends that potentially, every single copy of that first print run is unique. While detailing one difference between the various copies, he has "Whitman [stopping] the press, [rewriting] the line, and [resetting] it about a third of the way through the pressrun" (19). ${ }^{3}$ He also depicts Whitman, short of cash, directing his printers to bind together pages that he knew included typos, aiming for an approximate mean average of mistakes bound in each copy. Most scandalously, Ted Genoways has shown that Whitman instructed the engraver of the famous frontispiece portrait to alter the proofs of the engraving to increase the bulk of his crotch so as to better illustrate his notion of a "goodshaped and wellhung man." Leaves of Grass, from these points of view, is a set of books comprised of quick-fixes, amendments, accidents, improvisations, and experiments.

Dowling's argument also skirts around what I see as the crucial jack-of-all-trades aspect of Whitman's life. Biographers have long noted the ways Whitman's printing, poetry, and publication was influenced by his various experiences of farming, carpentry, teaching, and journalism, but they have not fully explored his deep engagement in New York's burgeoning real estate market. If he kept a close watch over the movements of the literary marketplace in the run-up to his first book of poems, then he also had a keen eye on the progress of the notoriously unstable housing market, the market in which he had invested most of his family's money and on which their financial security depended. I want to suggest that Leaves was also shaped by Whitman's management of Brooklyn real estate between 1848 and 1855, and that the complications, litigation, transactions, and bureaucracy involved in getting these structures off the ground directly impinged upon the development of Leaves. I shall go on to say that the notoriously unstable urban market, and the formulations of a provisional, transacting self in response to this context, provided a prototype for the fugitive Whitmanian "I." Whitman, in the years leading up to 1855 , forged a restless marketplace persona- "Walter Whitman Jr." - deploying it repeatedly while composing receipts, inventories, contracts, and house-plans.

This self was provisional in the sense that it represented the activities of an urban speculator in a state of perpetual negotiation-buying land, hiring labor, organizing construction and selling the product. The fluctuating "currency" of this transacting self on paper-its buying power, its reputation, its credibility, its security-was contingent on canny interactions with a severely unpredictable market. Walter Whitman Jr. successfully sidestepped a real estate crash in the spring 
of 1854 which could easily have eradicated his transacting capability altogether, making both him and his family bankrupt. Indeed, there was a real urgency to these negotiations; Walter Whitman Jr.'s stock was not so high as to enable him to direct his affairs from a secure family home. When Whitman bought and sold his houses, he was forced to move the entire family along with him. With two aging parents and a severely disabled brother to think about, this great period of creativity was sinewed with a weight of responsibility.

My argument builds on two important critical works: M. Wynn Thomas's seminal study of Whitman's work The Lunar Light of Whitman's Poetry and Andrew Lawson's more recent Walt Whitman and the Class Struggle. ${ }^{5}$ Thomas makes the valuable connection between the invigorating force of antebellum capitalist economy and Whitman's notion of "Kosmos." He states that "[Whitman] transform [s] the capitalist spirit by which his society was in fact animated into the indwelling spirit of the living universe" (80). He goes on to say that Whitman's poetry manages to resolve his conflicting feelings about "the uncompromisingly competitive origins of [capitalism's] exciting energy," by "desocializing and 'naturalizing' this energy" within the idealized realms of an organicist system (79). Thomas pinpoints one of the central tensions in Whitman's work - the notion of the poet as being caught in a post-artisanal phase of production. Leaves of Grass expresses the conflict between the nostalgia Whitman felt for the disappearing artisan class and the new possibilities inherent in the developing free market. My work differs in its approach to the formation of Whitman's poetic "self." Thomas suggests that "the conception and genesis of Whitman's Self should be sought not only in his efforts to avoid becoming a possessive self, but also in his determination to avoid being appropriated by others" (51).

A biographical inaccuracy in Thomas's work and Whitman studies in general has distanced Whitman the real estate developer from Whitman the poet. Whitman is aligned too strongly with his artisan background - as someone forced out of economic activity by the real estate crash of spring 1854. But as numerous receipts and building plans show, Whitman was not a victim of this crash; in fact he carried on speculating and developing well into 1855. Thomas describes Whitman's real estate involvement as the activity of "his recent artisanal self" (35). This is not quite accurate-Whitman was a hirer of labour, an overseer of production. Because Thomas dissociates Whitman from this working context, he is able to describe him as a detached and disaffected observer, able to consciously criticize, subvert, and transform the energies of free market capitalism into his poetic creations. The poet is seen as an "alchemist" (78) — consciously undermining and redirecting socioeconomic forces into his transcendent fictions-rather than 
someone directly implicated in the systems he attempts to transform.

Expanding on Thomas's work, Andrew Lawson reads the first Leaves of Grass as a product of Whitman's uneasy relationship to class. The poet is figured as both "artisan and autodidact" (xix), a member of the lower middle class:

Whitman's first poetic production is marked by a mixture of self-assertion and anxiety, which can be traced to the uncertain position of the lower middle class as it moves from agrarian folkways to the urban marketplace. (4)

Lawson goes on to say that "Whitman catches . . . the energy of the marketplace, that space of assembled particularity where differences of value are established and resolved. . . . The speaker of 'Song of Myself' plunges into this space of motion and exchange, identifying himself with it" (14). My argument details why Walter Whitman Jr. unavoidably plunged into this space and how this crucially affected the development of the 1855 Leaves of Grass-questions that are central to an understanding of the poetry. Lawson falls foul of the same biographical inaccuracy as Thomas; he has Whitman " $[\mathrm{u}]$ nemployed in 1854 . . . work[ing] on his poems" (85). He therefore diminishes the poet's active involvement in the sphere of moneymaking during the crucial period of creativity between 1854 and 1855. As a result, his claim that Whitman "catches . . . the energy of the marketplace" becomes somewhat opaque. ${ }^{6}$ Whitman, in the run up to publication, was employed. Lawson's reading positions the poet in a succession of "liminal" spaces - stuck between classes, out of work, and in a state of "social and political isolation" (104). From this detached position he observes and converts the tensions of his society into his poetry-an account of creativity that neglects the pressures of the everyday.

I want to re-examine the run up to publication and thereby modify and develop both Thomas's and Lawson's important lines of argument. Both critics establish that Whitman channels the energy of the marketplace into his poetic fictions - that the restive Whitmanian self is somehow linked to the perpetual motion of exchange-but in the process they lose a sense of Whitman's intimate relationship to that market. Whitman the property speculator and Whitman the poet are contemporaries. He is not set apart from the socioeconomic energies he transfigures. Instead, his own capitalist activities create the dynamizing framework for his fictions; it is because Whitman is simultaneously a poet and an entrepreneur, rather than just a disaffected artisan poet or unemployed lower middle class poet-loafer, that he is able to establish a provisional, transacting self sufficient to withstand and dramatize the shifting realities of an unstable marketplace. ${ }^{7}$ His marketable transcendental fictions are molded by complicit and invigorating personal 
adaptations to a specific economic context. It is because he is personally tied into the stresses of the market - the need to provide for his family, the need to raise money in order to fulfill his creative ambitions - that his poetry produces such an abundance of restless forms.

I consequently want to suggest that this has implications for certain stylistic aspects of his work. John Hollander has provided an account of Whitman's style, describing it in terms of a new "metrical contract"; Whitman's "commitment is made not to convention, but to the poetic self." 8 In other words, the poet claimed to have created a prosody based on the unique and organic rhythms of personal expression, instead of the inherited structuring devices of the past. Hollander says that Whitman's poetry appears as if it has taken on the "natural form from the self that releases it." In fact, he continues, "the actual constituents of his metrical style are syntactic; his invariably end-stopped lines are connected by parallelism, expansions of sentence matrices, types of catalogue, and so forth" (204). I want to qualify this by saying that Whitman's metrical style is also inscribed by distinctive economic rhythms, rhythms that are shaped by an integrated experience of the marketplace. Whitman's dealings in the city found their rhyme in his escapist narratives of transcendence and circular wholeness. But by rerouting his lived experience of urbanity through these narratives of organicism, he produced a poetry of the "self" that was inscribed by the transacting patterns it attempted to move beyond. In writing Leaves of Grass - whether motivated by a need to transcend the stresses of his material exploits, seek empowerment through a completely new way of writing, or, as is more likely, an unfathomable, half-conscious confluence of these motives and more-he scores his poetry with a distinctive urban praxis. Whitman's organicist prosody is rooted-no-founded upon contingent adaptations to the synthetic world of antebellum realestate economics.

II.

In November 1845, Whitman published an article in The American Review entitled "Tear Down and Build Over Again." This was a treatment of what he saw as the "restless" activities of property speculators who were radically transforming the urban geography of Brooklyn. Whitman called attention to the "feverish itching for change" and the "dissatisfaction with proper things as they are" that characterised the urban developments of his city: "Let us level to the earth all the houses that were not built within the last ten years; let us raise the devil and break things!" On one hand, Whitman articulates a sense of loss at the destruction of many of the city's historically consecrated places; 
on the other, he is sure to point out that he is "by no means desirous of retaining what is old, merely because it is old" (213). He adds: "we would have all dilapidated buildings, as well as all ruinous laws and customs, carefully levelled to the ground, forthwith and better ones put in their places." He concludes by warning that "the blindness which would peril all in the vague chance of a remotely possible improvement, has something of the same mischief of the soul . . . [as] that father of restlessness, the Devil" (214).

In 1848, Whitman started taking an active part in the restless development of his city. By 1846, the Brooklyn housing market was enjoying an unprecedented boom. Williamsburg, a village of just 3,000 people in 1835 , had become a large town of 40,000 people by 1855 , the year it was absorbed by Brooklyn. ${ }^{10}$ Manhattan was becoming increasingly expensive, filthy, and overcrowded, and people were escaping in droves across the water. New transport links meant that the metropolis could be reached by cheap ferry crossing, so people were actually losing very little by moving out. This was the speculative bandwagon Whitman jumped on. And he was good at his job; by 1855, thanks to the sale of his house on Skillman Street, he was able to buy an un-mortgaged property for his family and on top of that, take the time off to organize and finance the publication of 795 books entitled Leaves of Grass. It is a curious irony to consider that Whitman, the champion of "Mannahatta""The beautiful city! the city of hurried and sparkling waters! the city of spires and masts! / The city nested in bays! my city!"-was able to pay for his initial poetic output because Manhattan, for many people, was becoming too dreadful a place to inhabit. ${ }^{11}$

In the following page from his notebook, Whitman describes his fidgeting movements between 1846 and 1859:

Moved into house in Prince st. in Dec. 1846

I built the place 106 Myrtle av. in winter of 1848-9, and moved in, latter part of April '49

I Sold the Myrtle av. house in May, '52, and built in Cumberland street, where we moved Sept. $1^{\text {st }}$, ' 52 .

Sold the two 3 story houses in Cumberland st. March 1853. moved into the little 2 story house Cumberland st. April $21^{\text {st }}$, '53 (lived there just one year exactly)

Built in Skillman st. and moved there May, 1854

Moved in Ryerson st, May 1855.-Lived in Classon from may $1^{\text {st }}$ '56,'7,'8, '912

Notice that most of the transactions occur around a specific date-May $1^{\text {st }}$. As a real estate developer, Whitman's year revolved around one highly stressful period of trading. On "May Day," or "Moving Day," leases expired across the city (Figure 1). This forced thousands of New Yorkers and Brooklynites to simultaneously move house. Families and their belongings were temporarily stacked up on the sidewalks 


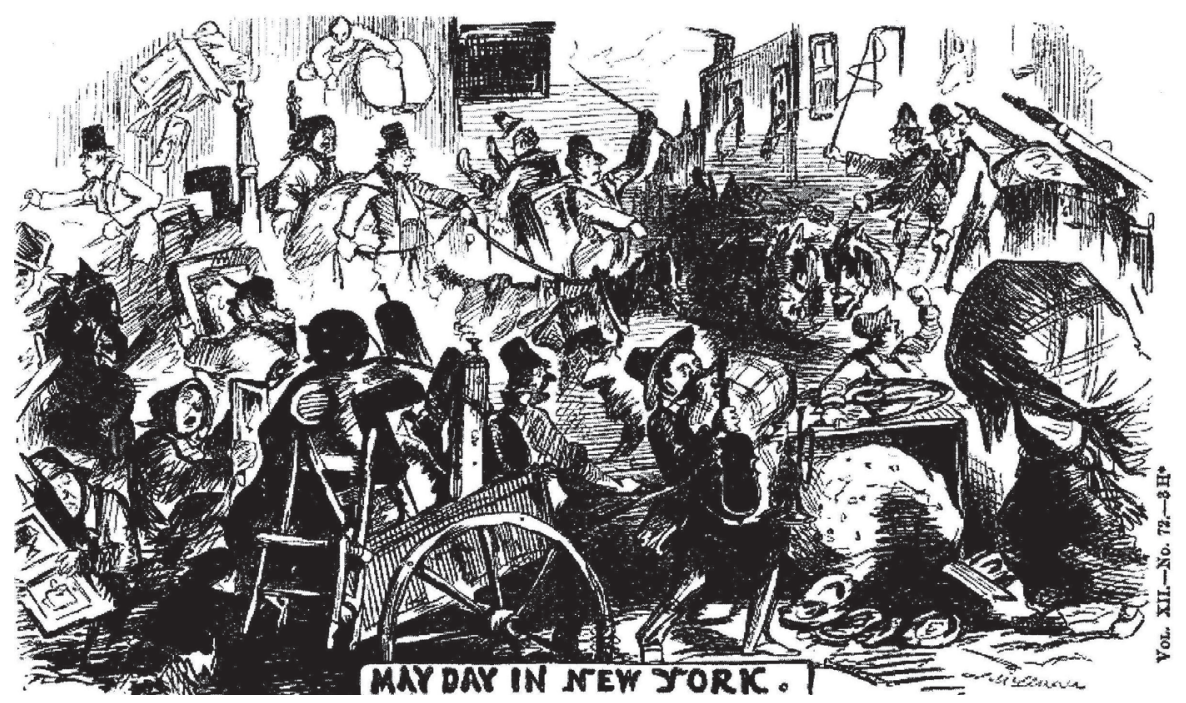

Figure 1. "May Day in New York," Harper's New Monthly Magazine (May 1856), 861.

as people scrambled for a new place to live. The sudden increase in demand enabled landlords to hike up rent and it was not uncommon to see open brawls erupt over the ensuing negotiations. ${ }^{13}$ On March 5, 1854, as Whitman prepared for the sale of his two newly built houses on Cumberland Street, a Brooklyn Daily Eagle article entitled "The Moving Season" complained of "the harassing and absurd custom that a great number of people have fallen into of changing their place of residence about the $1^{\text {st }}$ of May." This was "so troublesome, expensive and destructive of property, that the cause or motives which could have led to its origin must ever remain beyond conjecture."14 The upheaval of "Moving Day" was something that Whitman had to deal with. This was the time of year when people did real estate-it presented the best opportunities for buying and selling.

It was in tandem with this highly volatile housing cycle-in tune with the new growth associated with spring - that Whitman began, in 1848 , by selling the family home and building a three-story house on a plot of land he had recently bought on Myrtle Avenue, Brooklyn. In 1852, he sold this property for a good profit and immediately set about buying other plots of land on Cumberland Street. He contracted building firms to erect three further houses during 1852-1853. He sold two of these properties and moved into the other. From this address, he ran a shop with the sign "Carpenter and Builder" above the door. The sale of the Cumberland Street properties allowed him to build the house on Skillman Street (1854-1855). The family moved into this address in May 1854 and one year later, just before the book's publication in June, 
Whitman sold the property, his last and most profitable transaction. With the money raised, he bought a house outright in his mother's name on Ryerson Street and the family moved in. ${ }^{15}$ Whitman was jumping from house to house, project to project, becoming complicit in an urban restlessness of which he had previously complained. It is against this backdrop that Whitman writes lines like:

My ties and ballasts leave me . . . I travel . . . I sail . . . my elbows rest in the sea-gaps,

I skirt the sierras . . . my palms cover continents,

I am afoot with my vision.

By the city's quadrangular houses . . . . in log huts, or camping with lumbermen, Along the ruts of the turnpike . . . . along the dry gulch and rivulet bed, $[. . . .]^{16}$

These are the movements of the restive Whitmanian self, invigorated by the urban reality that forms its backdrop. The "I" is cast as a ship cut adrift, bereft of "ties" and "ballasts." Any rest the poet finds is only tangential, his elbows in sea-gaps, his palms stretching over continents. The poet starts his journey "By the city's quadrangular houses," leaping to "log huts" and then a lumbermen's encampment, before transforming into an elemental liquid that runs along the ruts of the turnpike and rivulet bed. This poetic vision is "afoot" with the provisionality of Whitman's own urban activities; it is the dramatization of a homeless self that cannot stop moving. ${ }^{17}$

Walter Whitman Jr.'s involvement in Brooklyn real estate development and the influence this had on the production method, themes and style of his subsequent book of poems has been significantly neglected in Whitman scholarship..$^{18}$ This is partly due to a chronological inaccuracy that has distanced Whitman the real estate developer from Whitman the poet. Joseph Jay Rubin claimed that "in the spring of 1854 the full force of the depression struck the entire metropolitan area. Banks dissolved, private credit vanished, failures came daily to Wall Street, 'to let' signs filled windows on Broadway and in Brooklyn." 19 This gives the impression that Whitman's real estate speculations suffered in a similar way-that he was forced out of the market prematurely. M. Wynn Thomas wrote more recently that:

[I]n the spring of 1854 came the slump that put [Whitman's] family, like thousands of others, out of work. Carpenters and printers, along with longshoreman, laborers, and the rest of the New York work force, flocked in such numbers to the soup kitchens that charitable food supplies were quickly exhausted. And it was during this period of enforced, but in his case welcome, idleness that Whitman, personally protected against the worst consequences of the depression, probably first seriously turned his 
No doubt the market collapse of spring 1854 had serious repercussions for many workers in the metropolitan area, but Whitman was not forced into the state of idleness that enabled him to turn exclusively to the work of writing. As numerous receipts and building plans show, the developing poet was still fully engaged in property speculation right up until May $1855 .{ }^{20}$ In fact the market uncertainty made property a more pressing concern. Again-his family's financial security depended on him not screwing this up. Whitman the real estate developer and Whitman the poet are integrated contemporaries. In the year leading up to the spring and summer of 1855 , Whitman had two ambitions: to successfully sell a house come the moving season and to publish a book in June. In November 1854, as Whitman shaped and reshaped the lines that would be incorporated into Leaves of Grass, he was also organizing substantial improvements to the Skillman Street property, turning parts of the then family home into a building site; as he revised his poems, he was simultaneously revising an agreement with his builder, his poetic and building projects becoming curiously syncopated. The following plan, apart from the signature at the bottom, is in Whitman's hand:

Transposing front door to wall between rooms and back window to place of door, weatherboarding under it, removing stoop in front, finishing and setting door in their places, complete in every respect-Building an $12[\mathrm{ft}] \mathrm{x} 11[\mathrm{ft}]$ shed in rear with sealing boards one side planed, roof well battened, with one good sized batten door-Making fence across rear of yard-setting joist partitions in $2^{\text {nd }}$ story, two doors, battens, windows and doors cased, base around rooms, furring overhead as agreed upon, and all furring \&c, including everything necessary for the masons to commence work-black latches and bolts to the three doors - everything complete and done in a workmanlike manner-Work and materials forty five dollars.-

Received Brooklyn Nov. $14^{\text {th }} 1854$ of Walter Whitman twelve and a half dollars in advance on acc't of the above job to purchase materials - the job to be done by the $1^{\text {st }}$ of December, unless prevented by bad weather or sickness

[Charles Burton $]^{21}$

As this document shows, Whitman took a predominantly administrative role in the construction process-hiring builders, sketching designs, writing receipts - rather than contributing manually. ${ }^{22}$ Here and there, we get traces of an artisan's knowledge, requesting that the roof be "well battened, with one good sized batten door" and that things are in order for the mason to start work. But the document is also governed by the voice of an entrepreneur giving orders to his workforce. ${ }^{23}$ What needs amplifying here is the vibrantly new socioeconomic stance implied by this document. Whitman was straddling the increasing divide between artisan builder and capitalist opportunist. Thomas has 
in the post-artisanal phase the function (and with it the whole status) of the producer is fundamentally altered. He now produces for a middleman who deals in a complex, increasingly remote, and demanding market. In the first instance this intermediary may be only the distributor of the product, but even then he soon comes to dictate the terms of production. . . . Under this arrangement the former artisan, now effectively a supplier or hirer of labor in return for money, finds himself deeply implicated in a system of relations which alter his whole conception of himself and his work. . . . He lives by the competitive accumulation of capital, rather than by virtue of what he produces through the exercise and public demonstration of patiently acquired skills. (69-70) ${ }^{24}$

So, for example, Whitman built to sell but was forced to move his family from newly built house to newly built house in order to cut living costs; he was also not so detached from the production process that he was saved from having to fix the minor problems that always emerge when overseeing any construction project, especially when getting everything in order for the rush in May. His article "Tear Down and Build Over Again" is a manifestation of the conflict he struggled with throughout these years - an acute sense of vanishing tradition pushing against his own complicity in the rise of the restless free market. One can imagine a similar working relationship between Whitman and the Rome Brothers printing firm-with Whitman ordering revisions and alterations for others to execute whilst simultaneously chipping in with the advice of someone who was knowledgeable about the printing process. ${ }^{25}$ One might ask why Whitman gave the job of printing to the Rome Brothers when he had extensive knowledge of the trade and could probably have hired the necessary equipment and completed the job himself. The answer may lie in the fact that Whitman now had experience of a new mode of production-derived from his real estate dealings - which enabled him to combine a managerial perspective with an artisanal expertise. In this sense his house building fed into his book making, providing him with an effective new way of directing a workforce from the simultaneously detached and involved perspectives of the printer/artisan-come-manager. Ed Folsom has described the juggling calculations and measurements Whitman made whilst negotiating with his printers - the necessary reshapings of book size and layout to accommodate the capacities, time limitations, and paper supplies of his workforce. Folsom also claims that "the arrangement of the poems in the first edition . . . clearly seems to be . . . based on spatial concerns rather than on thematic ones." 26 Whitman was conflating formal production methods here, forming similar creative working relationships with printers and builders alike. 
This conflation is apparent in the experimental changes that were made to the 1856 edition of Leaves. That book had 394 pages housing thirty-two titled poems. Twenty of them were new, including "BroadAxe Poem," "Sun-Down Poem" and "Poem of the Road." Whitman's long lines were fitted into the limited space of small pages, causing the lines to spill over into more homogenous-looking blocks of language. ${ }^{27}$ The frontispiece portrait now filled its page almost entirely. There was also a "Leaves-Droppings" section annexed to the back of the book that contained Emerson's complimentary letter and Whitman's open response. It also included eight reviews of varying degrees of praise, bafflement, and outrage (two by Whitman himself), and the results of Whitman's phrenological report. Whitman was tacking things on-adding extensions to a structure that had undergone major refurbishment. The book format becomes a metrical device which governs the visual aspects of the text as well as the rhythmic potential of words. Words are re-housed and so are forced to adapt to their new confines - they implicitly speak through the rhythms of Whitman's active urban engagement.

This is a passage from the second poem of the 1855 edition, later entitled "A Song for Occupations":

Grains and manures . . marl, clay, loam . . the subsoil plough . . the shovel and pick and rake and hoe . . irrigation and draining;

The currycomb . . the horse-cloth . . the halter and bridle and bits . . the very wisps of straw,

The barn and barn-yard . . the bins and mangers . . the mows and racks:

Manufactures . . commerce . . engineering . . the building of cities, and every trade carried on there . . and the implements of every trade,

The anvil and tongs and hammer . . the axe and wedge . . the square and mitre and jointer and smoothingplane;

The plumbob and trowel and level . . the wall-scaffold, and the work of walls and ceilings . . or any mason-work: [ . . . . ] (LG 1855, 61-62)

This is the same passage in 1856 :

Grains, manures, marl, clay, loam, the subsoil plough, the shovel, pick, rake, hoe, irrigation, draining,

The curry-comb, the horse-cloth, the halter, bridle,

The barn and barn-yard, the bins, mangers, mows, racks,

Manufactures, commerce, engineering, the building of cities, every trade carried on there, the implements of every trade, 
The anvil, tongs, hammer, the axe and wedge, the square, mitre, jointer, smoothing-plane,

The plumbob, trowel, level, the wall-scaffold, the work of walls and ceilings, any masonwork, [ . . . . ] $(L G 1856,131)$

Notice the culling of conjunctions and dotted ellipses, which moves the poem away from the more paced metrical arrangement of interspersed rising duple and triple metres of 1855: "the shovel and pick and rake and hoe." This is pared down in 1856 to "the shovel, pick, rake, hoe, irrigation, draining." These revisions experiment with new ways of "jointing" words. ${ }^{28}$ The removal of conjunctions condenses the stresses within the line and more explicitly recasts it as an inventory. Henry David Thoreau, having been given a copy of this edition by the author, said that: "By his [Whitman's] heartiness and broad generalities he puts me into a liberal frame of mind prepared to see wonders . . . and then - throws in a thousand of brick." ${ }^{29}$ The metaphor is apt - this is a new arrangement of the raw materials. The blanket-application of the comma in 1856 is an experiment in rhythm. In the future editions of this book, this will change again, but for now, Whitman decides that this technique will serve as a provisional solution.

Some lines from Leaves of Grass appear in three different forms between 1855 and 1856. These are lines from 1855:

Pasturelife, foddering, milking and herding, and all the personnel and usages; The plum-orchard and apple-orchard . . . gardening . . seedlings, cuttings, flowers and vines, [ . . . . ] (LG 1855, 61)

\section{6 reads:}

Pasture-life, foddering, milking, herding, all the personnel and usages,

The plum-orchard, apple-orchard, gardening, seedlings, cuttings, flowers, vines, [ . . . . ] $(L G 1856,131)$

And in "Leaves-Droppings" the lines from the London Examiner supposedly quoting from 1855 edition read:

Pasture-life, foddering, milking and herding, and all the personnel and usages;

The plum-orchard and apple-orchard, gardening, seedlings, cuttings, flowers and vines, [ . . . . ] (LG 1856, 380).

The extract from the review either shows the reviewer altering Whitman's punctuation by leaving out the dotted ellipses, or they show 
Whitman's work as it looked during the process of revising the first volume. More probably the latter, because every review included in the annex removed all traces of Whitman's ellipses. The poet has let the reviews stand, but not the poems they quote. Whitman also corrects "Pasturelife" to "Pasture-life," which updates the word to its 1856 appearance even though it is quoted as the 1855 text. Taken together, these three cross-sections show the poet restlessly rehousing and refitting his words, unable to settle on a permanent solution, again curiously syncopating the dynamics of his urban movements with his creative output.

In later life, Whitman tended to obscure the predominantly administrative role he had played in his building projects in order to align this period with the overly nostalgic artisanal mythologies that were perpetuated by his friends and admirers: ${ }^{30}$

My father was a carpenter and came into that trade by inheritance. So I set to work at it after I gave up editing newspapers. I built the building which is at 100 Myrtle avenue. Afterward I added an extension to it in the rear yard, where I did job printing in connection with my building enterprises. Before long, however, I got the chance to sell this place at quite a good penny and let it go. I had begun to think of making my fortune as a builder. I bought several lots on Cumberland street, between Fulton street and Atlantic avenues, where I put up five houses, all of which I soon sold at a good penny. I now had quite a little sum of money in hand. But I got a bee in my bonnet and took to the pen. I soon published 'Leaves of Grass.' I ought to have stuck to the building of houses and buying real estate. If I had I should be a man of means now. As it is I am only the author of 'Leaves of Grass.' 31

By casting himself as either a carpenter or, as with some instances in the notebooks and poems, a builder/architect-"I see them building churches to God . . . I If I build a church it shall be a church to men and women" (NUPM, 146) - he assimilated the development of the 1855 Leaves of Grass within the organic narratives of the skilled artisan, a figure who "learns their trade by inheritance," who gains a spirit or knowledge that is passed down from generation to generation. Whitman's early biographers John Burroughs and Richard Maurice Bucke-whose biographies were the product of interviews with the poet and even included Whitman's own amendments-both relay the putting together of Leaves in artisanal building metaphors:

In 1855, then, after many manuscript doings and undoings, and much matter destroyed, and two or three complete re-writings, the essential foundation of Leaves of Grass was laid and the superstructure raised. ${ }^{32}$ 
By the spring of 1855 , Walt Whitman had found or made a style in which he could express himself, and in that style he had (after, as he has told me, elaborately building up the structure, and then utterly demolishing it, five different times) written twelve poems, and a long prose preface which was simply another poem. ${ }^{33}$

Bearing in mind Whitman's actual activities leading up to the production of Leaves of Grass, it is extremely suggestive to speak of the poetry's development in the terms of a restless process of building up and demolishing, of reshaping and remodelling. What obscures the potency of these critical metaphors is the caricature of Whitman as himself a builder or carpenter. He was neither of these things - instead he was implicated in the rise of a new post-artisanal bourgeoisie, a group of middlemen that had started cutting their ties to the domain of labor and production. It was his active exposure to, and engagement with, the vibrant energies and implications of this new predicament that Whitman channels into the construction of his poetry.

III.

When Whitman wrote out the receipts for labor costs, title deeds, and housing contracts, he adopted the marketplace persona, "Walter Whitman Jr.":

Brooklyn, October $23^{\text {rd }} 1852$. Received of Walter Whitman, Jr. Fifteen Dollars, in part payment of work done by me, by contract, on houses in Cumberland Avenue [Signed Scofield]

Brooklyn, June $14^{\text {th }} 1853$, Received of Walter Whitman, Jr. Sixty Five Dollars, being payment in full of all demands on my contract for carpenter work and materials on two story house in Cumberland St. [Signed Hedges]

Brooklyn, June $3^{\text {rd }} 1854$ Received of Walter Whitman Jr. One Hundred Dollars, as first payment On Work in Skillman St. [Signed Smith \& Selleck] ${ }^{34}$

Whitman wrote the majority of his receipts himself and then handed them over to be signed. The formulation in these dockets is repeated again and again: "Received of Walter Whitman Jr." This third person construction posits a provisional, transactional self sufficient to withstand the shifting contingencies of the marketplace. Whitman writes out ephemeral selves validated only in the moment of the specific transaction, in the moment of a specific set of marketplace circumstances. This self floats above the tactile domain of labor in the realm of economic exchange. The validity of "Walter Whitman Jr." is contingent on the forces that created it. Without the currencies of economic reality that pass through it, this self is left derelict, up for rent, no longer the conduit for the 
economic rhythms that gave it relevance. "Walter Whitman Jr." is a product of the marketplace; when stripped of its animating context, it is left a conceptual husk, or an empty vehicle now capable of conveying or channelling other freight.

The first edition of Leaves of Grass is strewn with the linguistic remnants of this economic world, removed from the context that created them and redeployed as vehicles that transmit Whitman's narratives of organicism. This is for example traceable in Whitman's manipulation of the preposition of. What does the of do in the repeated formulation "Received of Walter Whitman Jr."? Portia in The Merchant of Venice asks: "What ring gave you, my lord? / Not that, I hope, which you received of me" (5.1.183-184). Of takes on the function of from in these exchanges, which allows the sentence to convey transaction: Bassanio has received of Portia a ring.

John Hollander, discussing the "multivalent service" provided by the preposition of in "Song of Myself" says that "a 'Song of Y' could be about Y, composed by Y, composed of Y, from (the land of) Y, etc." ${ }^{35}$ This last option requires nuance-a "Song of $\mathrm{Y}$ " is not only a "Song from the land of $\mathrm{Y}$ " but also crucially a "Song received from Y," an exchange from poet to reader-something that is formulated more explicitly at the beginning of what would later become "A Song for Occupations":

Push close my lovers and take the best I possess,

Yield closer and closer and give me the best you possess. ( $L G 1855,57$ )

Whitman's poetry is scored with the lived inflections of economic exchange. In the following readings, I will show how Whitman's experience of the housing market is manifested in the poetry, and I will offer an alternative account of some aspects of Whitman's prosody:

I fly the flight of the fluid and swallowing soul,

My course runs below the soundings of plummets.

I help myself to material and immaterial,

No guard can shut me off, no law can prevent me.

I anchor my ship for a little while only,

My messengers continually cruise away or bring their returns to me. ( $L G 1855,38)$

The "I" of this passage is figured as an all-engulfing elemental liquid, capable of swallowing up the cosmos; this overwhelming force subsumes any earthly plummet that attempts to sound the depths of a universe only it can fathom. It is the embodiment of universality, capable of 
baptizing everything - both material and immaterial-in its infinite range. And yet sustaining this all encompassing self is the language of production and consumption. ${ }^{36}$ The "fluid and swallowing soul" is an insatiable scavenger; the "I" is a phantom mouth that helps itself indiscriminately to everything. The course of this "I" runs beneath the sounding of plummets, divorced from the tactile world of human production, and comes into being only at the provisional moment of transaction, the moment when it manifests its consumptive power on the page: "I help myself to." It anchors itself to enable the transacting messengers to bring back their "returns." The movement of this self is attuned to the restlessness of Whitman's urban activities; he stays still only in the moment of exchange-he then moves on.

When the poet praises the animal kingdom, he does so because:

Not one is dissatisfied . . . not one is demented with the mania of owning things, Not one kneels to another nor to his kind that lived thousands of years ago,

Not one is respectable or industrious over the whole earth.

So they show their relations to me and I accept them;

They bring me tokens of myself . . . . they evince them plainly in their possession.

I do not know where they got those tokens,

I must have passed that way untold times ago and negligently dropt them, [ . . . . ] (LG 1855, 34)

After differentiating animals from the realm of human socioeconomic relations - they are not dissatisfied, they do not own, they are neither industrious nor respectable-Whitman implicates them into an alternative system of universal "tokens," which is floated on a transparent interspecies stock market: "They bring me tokens of myself." This carries the market connotation "from myself"-tokens from himself that he negligently dropped untold times ago which have now been brought back to him. In the act of articulation, when the transcendent "I" reveals itself on the page, it does so by inhabiting a rerouted vocabulary of exchange. The animals inhabit a world where "Not one kneels to another nor to his kind that lived thousands of years ago," and yet it is they that subserviently bring tokens back to the poet who "passed that way untold times ago." This is shaded in terms of a deference towards a supervisor; the animals show their relations and are "accepted," as if making a sales pitch to a possible client. The passage attempts to undermine the human world of ownership with a vision of a new transcendent natural order, and yet it does this by transposing the very patterns it seeks to repudiate. This is language that pushes against the discourse that makes it possible. 
When the child asks "What is the grass?," the poet responds with several interpretations:

I guess it must be the flag of my disposition, out of hopeful green stuff woven.

Or I guess it is the handkerchief of the Lord,

A scented gift and remembrancer designedly dropped,

Bearing the owner's name someway in the corners, that we may see and remark, and say Whose? $(L G 1855,16)$

Although ostensibly an exchange of gifts, the handkerchief is still received of or from the Lord. It bears the owner's name and partakes in the language of "Whose?"-namely property. Consequently, neither the "Lord" nor the "grass" manage to avoid the subtle undertones of marketplace dynamics. The Lord's handkerchief, a metaphor for the grass, comes replete with a trademark inscribed in its corner. The temptation here is to assume that Whitman is subverting and subsuming the language of economics within the higher realms of an organic order, but these ideas are dependent on this terminology for their dynamic shape and potency. The structuring support provided by this economic linguistic framework is the foundation on which the poet's metaphors of organicism are articulated. Whitman's economic activities were in tune with the arrival of spring - he aimed to complete his housing projects by May $1^{\text {st }}$, the time of year when the growth of grass is at its most vibrant. Whitman conflates the cyclical realm of real estate economics within the cyclical rhythms of nature:

Parting tracked by arriving . . . perpetual payment of the perpetual loan, Rich showering rain, and recompense richer afterward. ( $L G 1855,33)$

The patterns of parting and arriving, payment and repayment, giving and receiving provide the rhythmic arrangement for many of Whitman's lines. What the poet assumes, the reader assumes, for every atom belonging to the poet as good belongs to the reader: "I will be even with you, and you shall be even with me" ( $L G 1855,57)$. In 1856, Whitman wrote "Sundown Poem," later entitled "Crossing Brooklyn Ferry":

Flow on, river! Flow with the flood-tide, and ebb with the ebb-tide!

Frolic on, crested and scallop-edged waves!

Gorgeous clouds of the sun-set, drench with your splendor me, or the men and women generations after me!

Cross from shore to shore, countless crowds of passengers! 
Stand up, tall masts of Manahatta! - stand up, beautiful hills of Brooklyn! (LG 1856, 219)

In this ecstatic vision, the hills of Brooklyn stand shoulder to shoulder with the masts of Manhattan, and the flow and ebb of the river find their rhymes in the crossing from shore to shore of the countless crowds of passengers - this is the ultimate syncopation of economic activity and organic tempo. The perpetual transfers of the marketplace have been assimilated into the rhythms of nature's ebb and flow. This is the rhythmic consummation towards which much of the 1855 poetry struggles:

Eyes well apart and full of sparkling wickedness . . . . ears finely cut and flexibly moving.

His nostrils dilate . . . my heels embrace him . . . . his well built limbs tremble with pleasure . . . . we speed around and return.

I but use you a moment and then I resign you stallion . . . . and do not need your paces, and outgallop them,

And myself as I stand or sit pass faster than you. ( $L G 1855,35)$

The horse here is described in all of its potential - it is a beautiful symbol of life, eyes full of sparkling wickedness. The poet then mounts the animal and uses it to speed around and return, acting as ordering conduit of its movement. The stallion is harnessed by a promiscuous self that uses it only for a moment; it rides this organic symbol only temporarily, drawing the pattern of exchange with its steps before dismounting and resigning it.

A horse is used again in Leaves of Grass:

Sure as the most certain sure .... plumb in the uprights, well entretied, braced in the beams,

Stout as a horse, affectionate, haughty, electrical,

I and this mystery here we stand. ( $L G 1855,14)$

The "I," at a remove from the process of production, confidently gives commands to the invisible workforce ordered to plumb in the uprights, making sure the structure is "well entretied" and "braced in the beams." Then comes a metaphorical sleight of hand as the structure is compared to a stout, affectionate, haughty, and electrical horse-a body that serves to confuse a natural creation with the mechanical domain of labor. The "I" then assuredly steps back and announces: "I and this mystery here we stand," leaving the reader wondering what "mystery" is referred to-the house or the horse. The productive forces that went 
into building the structure in the first place are successfully obscured. A process of metaphorical mystification subjugates the invisible workforce laboring under the command of the poet.

This detached, commanding presence asserts itself again with the introduction of the poet's name:

Walt Whitman, an American, one of the roughs, a kosmos,

Disorderly fleshy and sensual . . . e eating drinking and breeding,

No sentimentalist . . . . no stander above men and women or apart from them . . . . no more modest than immodest.

Unscrew the locks from the doors!

Unscrew the doors themselves from their jambs. ( $L G 1855,29$ )

As the "I" announces itself triumphantly in the third person- "Walt Whitman, an American, one of the roughs, a kosmos"-we are presented with a persona seemingly distinct from the Walter Whitman of the verso of the title page who registered his product at the clerk's office in 1855. But the administrative "Walter" and the poet "Walt" are not easily separable; unlike Walter Whitman Jr. who employs a workforce to build his houses, Walt claims not to stand "above men or women or apart from them," and yet in the two subsequent lines we hear a remnant of an administrative voice ordering an invisible workforce to "unscrew the locks from the doors! / Unscrew the doors themselves from their jambs." The liberating cry finds expression within the residual language of market relations.

These examples demonstrate the ways in which the traits of economic negotiation manifest themselves more generally within the organicist patterns of the poetry. I now want to show more precisely how the rhythms of exchange, speculation, and of tearing down and building up again, form some of the distinctive building blocks of Whitman's prosodic innovations:

Extreme caution or prudence, the soundest organic health, large hope and comparison and fondness for women and children, large alimentiveness and destructiveness and causality, with a perfect sense of the oneness of nature and the propriety of the same spirit applied to human affairs . . these are called up of the float of the brain of the world to be parts of the greatest poet from his birth out of his mother's womb and from her birth out of her mother's. ( $L G 1855$, ix)

Notice the successive repetitions of the genitive "of," ostensibly indicating the relational bonds of universal consanguinity: human affairs are called up "of the" float "of the" brain "of the" world. Encoded in this text is the sense of a thing's value being contingent on its relationship to something else. What remains are the husks of an economic rela- 
tional matrix - of concepts being successively annexed by Whitman's double-edged repetitions of of towards a point of beginning or store. The anapestic rhythm produced in sentences like "of the float of the brain of the world to be parts of the greatest poet" traces a rhythmic restlessness of mind that trades with a concept only briefly before moving on to seek commerce with another. In this way, Whitman creates poetic shapes that imitate his urban restlessness:

I bequeath myself to the dirt to grow from the grass I love, If you want me again look for me under your bootsoles.

You will hardly know who I am or what I mean, But I shall be good health to you nevertheless, And filter and fibre your blood.

Failing to fetch me at first keep encouraged, Missing me one place search another,

I stop some where waiting for you $(L G 1855,56)$

In these famous final lines of what would eventually become "Song of Myself," the "I" of the poem bequeaths himself to the dirt so as to become part of the natural rhythms of rebirth and growth. Then we have the unforgettable line about the "bootsoles"- the poet apparently reimagining himself as the trodden-upon grass. Certain members of Whitman's family, when reading this, picked up on the hubris of an injoke. Among Whitman's receipts during his real estate days are several dockets for boots; Whitman consistently paid for his brothers' boots and boot repairs - twice in 1850, once in 1852, and twice in $1854 .{ }^{37}$ Unavoidable are the personal connotations of this statement. Whitman, by asking his closest family readers to look for him under their bootsoles, also quietly drew attention to the floor they stood upon, the successive roofs over their heads that were provided every May Day as a result of the poet's hard work. Whitman stops somewhere to wait-always ahead of the game. The physical, syntactic, and prosodic structures he constructs whilst temporarily stationary become his permanent poetic legacy. That is, until he tears them down and builds them up again in 1856, 1860, 1867, 1871, and 1881 .

IV.

Leaves of Grass has, of course, been read as entirely other to the context I have laid out above. In many ways, Whitman's poetry seems to bear little relation to the new economic order of antebellum America; there are so many aspects of Whitman's poetry that will always stand taller than any critical explanation. But by grounding his poetic achieve- 
ment within a specific context of an emergent capitalist economy, I am not attempting to explain the ongoing riddle of his radical creative genius - of why he wrote what he wrote. Rather, I have tried to offer what I admit is just one fragment of the extraordinary creative confluence that forged Leaves of Grass in 1855 and that, in part, shaped his subsequent books. By emphasizing how engaged with the needs of his immediate situation he was, I show that his work is imbued with very real, grounded human needs, inflected with the rhythms that were part of his everyday life. And perhaps this has something to do with Whitman's enduring appeal. Those crucial couple of years before he published his book have been seen as a period in which Whitman concentrated solely on poetry, fostering the myth that the poet works best when isolated in his creative tower. I think Leaves of Grass would be a weaker book if Whitman was not under pressure to perform financially-if he did not share in the struggles, hopes and weaknesses that haunt all human beings. The strange conflation of production methods, the mixture of quick-fixes, amendments and accidents, the desire to transform and escape the stresses of his situation, the pursuit of an extraordinary creative vision-all of these elements filter and fibre his work. They suggest a creative mind working in the half-conscious rush of everyday activity - creating something that only revealed itself on the day it was printed, and even then it changed and developed right up until the end of his life.

Leaves of Grass, then, is in part shaped by Whitman's movements between 1848 and 1855-his jumping from house to house-and is driven by the desire to provide for his family and publish his book. As Whitman built his houses, he became increasingly attuned to the springtime rhythm of the marketplace-Walter Whitman Jr., stripped of an economic context, became the transcendent conduit persona that organized the poem's organicist transactions and economies. "Walt Whitman, an American, one of the roughs" is a broker who deals in the currencies of mythic transcendental exchange. For the rest of his career Whitman would concentrate on tearing down, annexing, and building over again his subsequent poetic projects, aligning his imaginative undertaking with the restless rhythms of the city from which it was constructed. If Hollander figures the "constituents of [Whitman's] metrical style [as] syntactic," this syntax is shaded and inflected by the negotiations of a self that flits from situation to situation. In the moments of self-manifestation, when the self reveals itself in language, it channels itself through the cumulative rhythms of the real estate market. The shapes that are consequently made represent the shadows of a self that flies the flight of the urban speculator.

\section{University of Cambridge}




\section{NOTES}

1 See David Dowling, Capital Letters: Authorship in the Antebellum Literary Market (Iowa City: University of Iowa Press, 2009), 89.

2 See Ed Folsom, "What We're Still Learning about the 1855 Leaves of Grass 150 Years Later," in Susan Belasco, Ed Folsom, and Kenneth M. Price, eds., Leaves of Grass: The Sesquicentennial Essays (Lincoln: University of Nebraska Press, 2007), 15.

3 See also Gary Schmidgall's “1855: A Stop-Press Revision,” Walt Whitman Quarterly Review 18 (Summer/Fall 2000), 74-76, in which he discusses Whitman's stopping the print run of the 1855 edition in order to make a substantial change.

4 See Ted Genoways, “'One goodshaped and wellhung man’: Accentuated Sexuality and the Uncertain Authorship of the Frontispiece to the 1855 Edition of Leaves of Grass," in Leaves of Grass: The Sesquicentennial Essays, 100.

5 M. Wynn Thomas, The Lunar Light of Whitman's Poetry (Cambridge, MA: Harvard University Press, 1987); Andrew Lawson, Walt Whitman and the Class Struggle (Iowa City: University of Iowa Press, 2006).

6 Lawson brilliantly details how the "multifaceted language" of Whitman's poetry reflects and absorbs "the bewilderingly rich and complex range of texts circulating within the print culture of the antebellum period" (xxi). This reading however, is too heavily text orientated. Lawson argues that Whitman is part of the lower middle class - caught between social strata - and yet he confines his exploration almost exclusively to the realm of published textual sources. I want to put "Whitman the reader" to one side and focus on implications of "Whitman the money maker."

7 Matt Miller has recently argued that Whitman's "nomadic" lifestyle in the years leading up to 1855 left its mark on many of the stylistic elements of the first book: "the manuscript evidence suggests that the process of packing and unpacking text was crucial to his writing process, and the idea of mobile units of language powerfully informs most of the first edition" (51). Miller provides convincing and nuanced readings of the restlessness with which Whitman organized and reorganized his various draft lines. Yet with the use of "nomadic," he distances Whitman from an active participation in the housing market: "with Whitman's father, Walt Whitman Sr., quite ill and Walt Jr. distracted by other interests, including his artistic ambitions, the Whitman family profited only a little from the growing Brooklyn economy, despite their carpentry skills and the real estate speculation that led to their many moves" (48-49). Whitman was not "distracted" from his real estate dealings - on the contrary, they were a pressing concern because of the market uncertainty in the spring of 1854 . The fate of his houses and poems were intertwined and Whitman was forced to multitask. In May 1855, he negotiated the sale of his Skillman Street house, and with some of the profits was able to pay for the publication of Leaves in June. Whitman the real estate entrepreneur sinews Whitman the poet. See Chapter 2 "Packing and Unpacking the First Leaves of Grass," in Matt Miller, Collage of Myself: Walt Whitman and the Making of Leaves of Grass (Lincoln: University of Nebraska Press, 2010), 48-103.

8 John Hollander, Vision and Resonance: Two Senses of the Poetic Form (New Haven: Yale University Press, 1985), 204.

9 Walt Whitman, The fournalism, ed. Herbert Bergmann, Douglas A. Noverr, and Edward J. Recchia (New York: Peter Lang, 1998), 1:214, 211. 
10 Edward K. Spann, The New Metropolis: New York City, 1840-1857 (New York: Columbia University Press, 1981), 184. See also James E. Bunce and Richard P. Harmond, Long Island as America: A Documentary History to 1896 (London: Kennikat Press, 1977), 34.

11 Leaves of Grass (Boston: Thayer and Eldridge, 1860), 405. Available on the Walt Whitman Archive (www.whitmanarchive.org).

12 Walt Whitman, Notebooks and Unpublished Prose Manuscripts, ed. Edward F. Grier (New York: New York University Press, 1984), 1:11. Whitman started keeping this record in about 1850 and added to it as events changed. Grier notes that the dates at the end have been added to gradually over time in different inks.

13 See Elizabeth Blackmar, Manhattan for Rent, 1785-1850 (Ithaca: Cornell University Press, 1989) for a detailed description of this calamitous event: "As moving day brought all other trade to a halt and focused the commercial city's attention on the single commodity of shelter, the tensions of competing needs frequently erupted in the streets. Freely flowing liquor fueled and rewarded movers' exertions through the inevitable traffic jams and moving day brawls. Refusing to give up their homes, old tenants sometimes fought with new leaseholders, each side drawing support from crowds of relatives and acquaintances" (216).

14 The Brooklyn Daily Eagle (March 15, 1854).

15 Cleveland Rodgers, "The Good Gray House Builder," Walt Whitman Review 5 (December 1959), 63-69.

16 Leaves of Grass (Brooklyn: 1855), 35. Available on the Walt Whitman Archive (www.whitmanarchive.org). Hereafter, LG 1855.

17 This "homeless self" coexists with another American type of the period, the newly-emerging cosmopolitan, recognizable as Melville's Confidence-Man of course, but also as the travelling American.

18 Of very few critics who refer to this context, Ed Folsom has said that "Whitman's experience as a housebuilder may be relevant to the way he imagined book objects: when you needed more space for a new resident, you added an annex." Whitman Making Books/Books Making Whitman: A Catalog and Commentary (Iowa City: University of Iowa Obermann Center for Advanced Studies, 2005), 37. Folsom does not draw out this connection beyond this brief remark.

19 Joseph Jay Rubin, The Historic Whitman (University Park, PA: Pennsylvania State University Press, 1973), 298.

20 Andrew Lawson says that "in the winter of 1851 the banks collapsed, and there followed a 'veritable carnival of beggary by the unemployed.' In the winter of 1852 the journeymen carpenters were on strike for seventeen shillings a day. In the spring, Whitman set up as a builder and seller of small houses - a period of prosperity swiftly ended by the depression of the following spring, when banks and businesses once again failed and 'gangs of destitute young girls, filthy and obscene' roamed the streets. Unemployed in 1854, Whitman worked on his poems while mechanics marched with banners reading 'if work be not given we will help ourselves to bread"' (84-85). As is shown, this is not quite the case. Lawson is more accurate when he states that "succeeding where his father had failed, Whitman profited from his speculative investments in Brooklyn's expansion enough to make a cash payment of $\$ 1,840$ for a house on Ryerson Street. 'Song of Myself' reveals a Whitman seemingly caught up in the 
'market revolution'" (12). He does not take this line of thought any further-fortunately enough for the present essay. It is this sense of being actively "caught up" that I am trying to explore.

21 Papers of Walt Whitman in the Charles E. Feinberg Collection, Manuscript Division, Library of Congress, Washington, D.C., "Miscellany, 1834-1918," n.d. Box 50, Reels 32-33.

22 See Justin Kaplan's account of this in Walt Whitman: A Life (New York: Simon and Schuster, 1980): "It was Walt who patiently docketed the payment receipts for surveying and interest, lumber and paint, doors and window glass, brackets and moldings, sashes and blinds, tin and tinning, and it was Walt who drew up specifications for flooring, partitions, casings, shed roofs, stair rails, and masonry work, including 'Stone wall for cellar, chimneys and fireplaces, Plastering, Cistern, Privy, Cess Pool, Flagging in front,' and so on" (160).

23 The Feinberg collection contains similar documents relating to the construction of the houses on Cumberland Street in 1852-1853. Again we get the textured voice of the artisan-come-manager of labor. Structures were "to be framed complete, according to plan, with good stuff," and Mr. Hedges was also "to seal up the stairs with good sealing boards, so as to enclose the same tight up to the front door." Box 50, Reels 32-33.

24 Lawson sees this tension embodied in the rise of the lower middle class, a demographic in which he convincingly places Whitman (4-8). His focus, however, is on how these tensions manifested themselves in print culture.

25 See David S. Reynolds's discussion of Whitman's knowledge of the printing trade in Walt Whitman's America: A Cultural Biography (New York: Alfred A. Knopf, 1995), 6.

26 Ed Folsom, Whitman Making Books/Books Making Whitman, 10.

27 All quotations from the 1856 edition of Leaves of Grass are reprinted here with the line segments exactly as they originally appeared. Leaves of Grass (Brooklyn: [Fowler and Wells], 1856). Available on the Walt Whitman Archive (www.whitmanarchive. org). Hereafter, LG 1856.

28 Critics have acknowledged Whitman's development of more mimetic prosodic figures in 1856. See for example, James E. Miller, Jr.'s “'The Broad-Axe': Arising Shapes," in A Critical Guide to "Leaves of Grass" (Chicago: University of Chicago Press, 1957).

29 Letter from Henry David Thoreau to Harrison Blake, December 7, 1865, The Writings of Henry David Thoreau, ed. Franklin Benjamin Sanborn (Boston: Houghton Mifflin, 1894), 11:347.

30 In 1868, Whitman's friend and admirer William Doulas O'Connor published “The Carpenter: A Christmas Story" in Putnam's Monthly Magazine (January 1868), 55-90. Although Whitman's name was not mentioned explicitly, it is made quite clear that the mysterious "stranger" who arrives and makes everyone's Christmas better is meant to be a cross between Christ and the poet. This story followed O'Connor's The Good Gray Poet: A Vindication (1866), a highly sentimentalized portrayal of Whitman that, along with "The Carpenter," was to significantly influence later perceptions of him as a neglected, bearded, benevolent prophet replete with Christ-like carpentry skills and the ability to make (paper) butterflies perch on his extended finger.

31 "A Visit to Walt Whitman: He Recalls the Years When He Lived in Brooklyn [. . .] Leaving the Carpenter's Work to Turn Poet. What Might Have Been Had He 
Continued to Build Houses-Where 'Leaves of Grass' First Saw the Light," The Brooklyn Eagle (July 11, 1886), 10.

32 John Burroughs, Notes on Walt Whitman as Poet and Person (New York: American News, 1867), 83.

33 Richard Maurice Bucke, Walt Whitman (1883; rpt. New York: Gordon, 1972), $135,137$.

34 Feinberg Collection, Box 50, Reels 32-33.

35 John Hollander, The Work of Poetry (New York: Columbia University Press, 1997), 97, 102. Whitman occasionally writes "from" instead of "of": "Received from Walter Whitman Jr." But he stuck to the more archaic usage for the majority of his dockets. See Feinberg Collection, Box 50, Reels 32-33.

36 Richard Pascal has argued that "by overturning the standard meanings of terms associated with finance and commerce, Whitman attempts to twist capitalist discourse to his own purposes and subvert some of its basic assumptions without directly rejecting them" (149). See Pascal, “Dimes on the Eyes': Walt Whitman and the Pursuit of Wealth in America," Nineteenth-Century Literature 44 (September 1989), 141-172. I want to reorder this line of thought and argue that instead of "[twisting] capitalist discourse" to fit his organic agenda, Whitman's poetry filters his personal experiences of the marketplace to give his ideas form.

37 Feinberg Collection, Box 50, Reels 32-33. 